\title{
ВПЛИВ ПОЛІХРОМАТИЧНОГО ПОЛЯРИЗОВАНОГО СВІТЛА В ПОЄДНАННІ 3 БЛИЖНІМ ІНФРАЧЕРВОНИМ ВИПРОМІНЮВАННЯМ НА НЕЙРОГУМОРАЛЬНІ, ІМУННІ ТА ТКАНИННІ ЗМІНИ ПРИ ОПІКОВІЙ ТРАВМІ
}

\author{
С. О. Ґуляр ${ }^{1,2}$, Ю. І. Стрельченко ${ }^{2}$ В. М. Єльський ${ }^{2}$ \\ ${ }^{1}$ Інститут фрізіології ім. О. О. Богомольця НАН України \\ ${ }^{2}$ Інтернаціональний медичний інноваційний центр
}

\begin{abstract}
Експериментальні дослідження проведено на щурах, які отримали дозований вплив відкритим полум'ям на шкіру. Поляризоване світло позитивно впливало на функціональний стан центральної нервової системи при опіках. Активувалися антистресовий і адаптаційно-стимулювальний механізми. Встановлено, що під впливом поляризованого світла відбувається прискорене обмеження глибини альтерації дерми та вторинної альтерації тканин шкіри та підлеглих м'язів. Виявлено активацію механізмів обмеження запалення і посилення проліферації фібробластів. Це спостерігалося на тлі стимуляції формування грануляцій, неоангіогенезу, посилення міграції кератиноцитів та епітелізації поверхні рани.
\end{abstract}

Ключові слова: опікова травма, поляризоване світло, БІОПТРОН, ПАЙЛЕР-світло, центральна нервова система, морфогенез рани, нейрогормональна й імунна системи.

\section{INFLUENCE OF POLYCHROMATIC POLARIZED LIGHT COMBINED WITH NEAR-INFRARED RADIATION ON NEUROHUMORAL, IMMUNE AND TISSUE CHANGES AT BURN INJURY}

\author{
S. O. Gulyar ${ }^{1,2}$, Yu. I. Strelchenko², V. M. Jelskii ${ }^{2}$ \\ ${ }^{1}$ Bogomoletz Institute of Physiology of National Academy of Sciences of Ukraine \\ ${ }^{2}$ International Medical Innovation Center
}

\begin{abstract}
We performed experimental studies on rats who received dosed influence by open flame on the skin. We observed polarized light positive influence on central nerve system functional state at burns. There activated anti-stress and adaptive stimulating mechanisms. We singled out, that under the influence of polarized light, there occurs accelerated restriction of derma depth alteration restriction and skin tissues secondary alteration and sub muscles. We singled out activation of mechanisms that restrict inflammation, fibroblasts proliferation increase. We observed it on the background of stimulation of granulations formation and neoangiogenesis, stimulation of keratocytes migration and wound surface epithelialization.
\end{abstract}

Key words: burn trauma, polarized light, BIOPTRON, PILER-light, central nervous system, wound morphogenesis, neurohumoral and immune systems.

Вступ. Трансдисциплінарність - новий напрям у розвитку філософії науки, трансформації засобів сучасних наукових досліджень. Феномен трансдисциплінарності за ключовим змістом свого визначення є сполучною ланкою між розвитком наукового пізнання і вирішенням реальних проблем в житті людини, суспільства і культури [1].

Автором ідеї про необхідність «піднятися над вузькими інтересами і взаємодією дослідників, зайнятих рішеннями вузькоспеціальних проблем» вважається Ж. Піаже [2]. Трохи пізніше він же говорив про трансдисциплінарність щодо ситуацій, коли здійснювалася інтеграція понять і методів різних дисциплін, близьких за своєю структурою, методами і способами перевірки результатів.

Introduction. Thermal injuries occupy the second place in the structure of peace-time traumas (10$12 \%$ of all traumas) $[1,2,3]$. It is known that polarized light accelerates wound healing, but at present, there are single researches. They testify to high efficiency of application of visible range of electro-magnetic waves for burn wounds healing and rehabilitation of patients with burns [4, 5]. Monstrey et al. [6] reported statistically reliable acceleration 
of deep burns healing. Five independent research groups got unidirectional results for 67 patients with extensive burns of the second and third degrees. They consisted in daily application of polychromatic polarized light (Bioptron-2 device) on the burn area during six minutes and this provided more rapid epithelization of wounds edges, decrease of hypertrophy excrescences, diminishing or absence of contracture for shorter time period in comparison with control data (22 days opposite 41 days).

There are data, that in 20 patients with standard donor wounds, that the mentioned light influence reduced inflammatory reaction, accelerated granulations quality, epithelization, improved patients" feeling and early physiological cicatrization [6].

Experience of Polarized Incoherent Low Energy Radiation (PILER-light) application for 48 patients with the face and respiratory tracts burns on a background of general and local treatment by ordinary methods also testified to the light therapy positive results [7].

It is established, that light therapy application (Bioptron-2 device) promoted face and respiratory tracts edema diminishing, renewal of microcirculation in the stasis areas, near-by to the burn surfaces. It is singled out favorable influence of the polarized light on reparative processes, operative treatment results and character of postsurgical scars forming. Average hospital stay in the intensive therapy department decreased for 2-3 days.

PILER-light influence on the humane organism is determined by the wide biological effects spectrum: stimulation of regeneration, inhibition of inflammation, modulation of immune processes, renewal of microcirculatory violations, vegetotropic and analgesic action etc. $[8,9,10]$. But the pathogenic mechanisms of these effects need concrete proofs which circle is very limited in clinical practice.

There is no data about the mechanisms of PILERlight influence on the central nervous system functional state and morphogenesis of burn wound.

To get answers to these questions it is necessary to design pathological process (ambustial trauma), its dosage and study of different organism homoeostasis indexes under polarized light waves' influence in an experiment. Therefore, it became the purpose of this research.

Material and methods. The research was done on white not thoroughbred rats-males, of six months age, 180-220 g weight, with the observance of Helsinki declaration, accepted by General assembly of the World medical association (2010), and with permission of Commission on bioethics of the Donetsk national medical university from 2011/01/29 No 8/16 and from 2012/10/22 No 112/16.

To model a dosed burn by open flame we developed, patented and used the method [11], which allowed to measure exactly the degree and area of burns and approaches an experiment to the real terms of domestic or industrial fires. $5 \%$ of body area burns on the back and sacrum area were done.

Distance from the flame source to the skin was $15 \mathrm{~mm}$. Exposure was 3 seconds (instantaneous burn). In this case, epidermal and superficial dermal burns were done (according to the classification of the XX convention of surgeons of Ukraine, 2002). In addition to the clinical characteristics of the burn stage in each case was determined by microscopic picture of the burn zone. Exactly these kinds of burns are characteristic for domestic and industrial fires at the explosions of combustible gas. In this study, we used the standardized model of dosed burns by the open flame.

We used Bioptron-compact device (Zepter-Bioptron AG, Switzerland) which produce polarized (PILER) light stream of 12,3 $\mathrm{cm}^{\Gamma}$ area, and has poly- and monochromatic ranges. PILER-light influence, with part of infrared radiation (wavelength: 480-3400 nm, power density: $40 \mathrm{~mW} / \mathrm{cm} 2$, light energy per minute: $2,4 \mathrm{~J} / \mathrm{cm}^{2}$ ) was performed at $10 \mathrm{~cm}$ distance to the skin, during 10 minutes three times per day according to treatment recommendations for patients with burns $[9,10]$. At this distance, the diameter of the light field covered almost the entire back of the rat with an uncrippled skin. Thus, influence of the polarized light was not only local but also general.

To study PILER-light influence on ambustial wound cicatrization speed corresponded to the wound healing phases in a day, in three days, in a week and 11 days after trauma, we did morphometrical research of burn surface diameter and area. We compared the obtained data with analogous results in animals without piler light application (comparison group or placebo).

To estimate PILER- light influence on the burn wound morphogenesis (expression and dynamics of inflammatory reaction, development of granulations and epithelization process) we studied the morphology of burn wound. To estimate systemic reactions we studied central nervous system functional state. The functional state of central nervous system was estimated by methods of the «open field test» and «hole reflex test». We assessed orientation-moving activity of rats in the "open field" and latent time of animal getting in a dark chamber. 


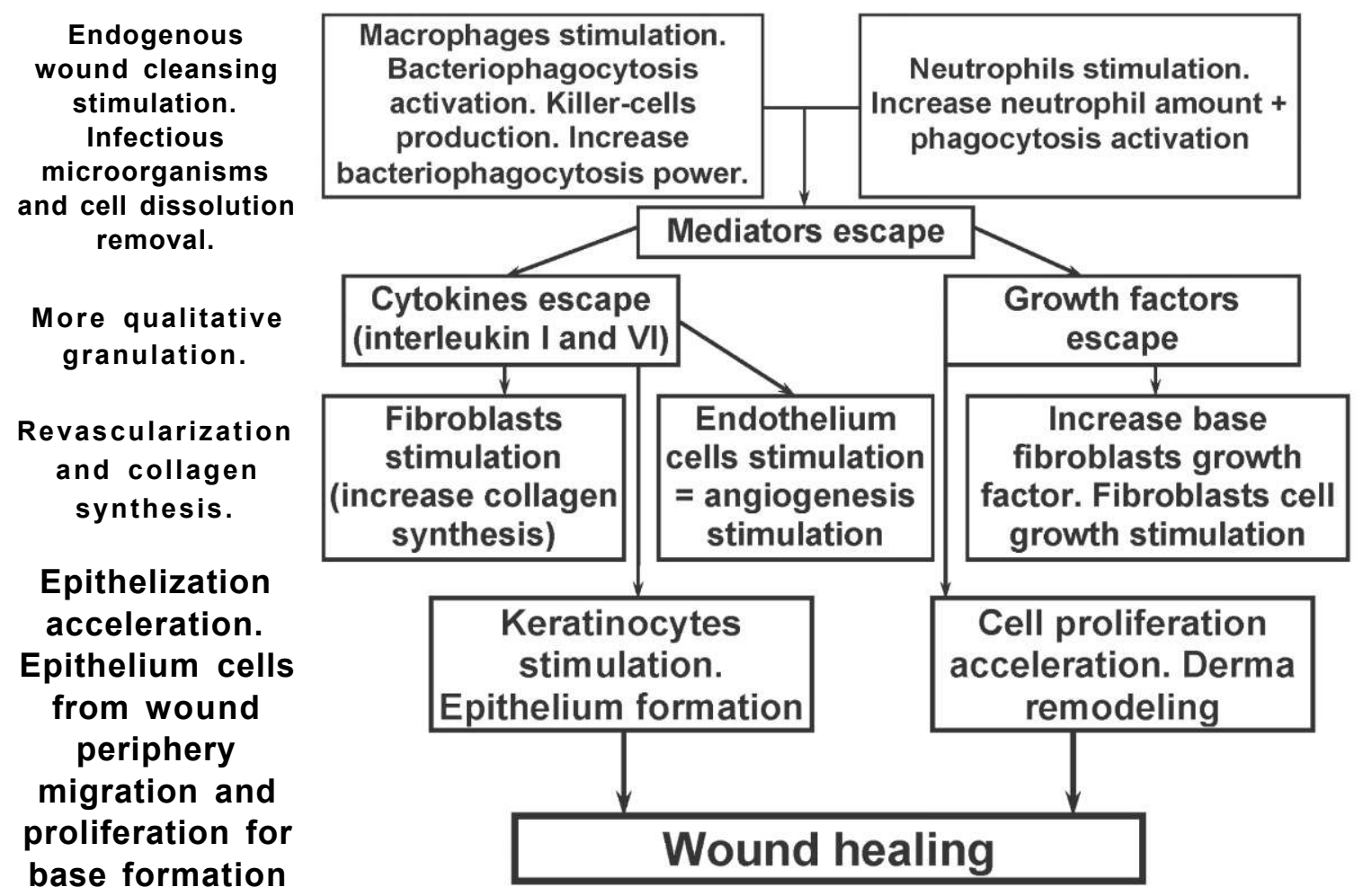

Fig. 1. Positive PILER-light influence on the burn wound morphogenesis

Results and discussion. Experimental burn model made it possible to get the standardized and reliable pattern of ambustial wound morphogenesis. The three-second exposure to the open flame caused epidermal and superficial dermal burn development. It was characterized by epidermis and superficial derma layers necrosis, development of intense tissue edema, which visualized in forming different size of bubbles and by the desquamation of necrotic changed epidermis.

Ambustial damage negatively influenced the central nervous system functional state, orientation-moving activity of animals changed in the "open field" test. We also observed intense diminishing of crossing squares amount for $72.9 \%(\mathrm{p}<0.001)$ and holes examination for $65.7 \%(\mathrm{p}<0.001)$ in relation to intact animals. Data obtained after the polarized light application, convincingly testified to positive PILER-light influence on the ambustial wound morphogenesis (fig. 1).

We observed the increase of ambustial surface cicatrization speed on the 7th day, the ambustial surface diameter decreased for $20 \%(\mathrm{p}=0.005)$ and area - for $36 \%(\mathrm{P}<0,001)$ in comparison with the placebo group. In 11 days the ambustial wound diameter decreased for $38.6 \%(\mathrm{p}<0.001)$, and area - for $62.3 \%(\mathrm{p}<0.001)$ in relation to the group of comparison.

Morphometrical research data were cytologicaly confirmed (light microscopy). The PILER-light action determines spatial and chronologic changes of vascular and proliferative components of inflammation course.

First, it promoted limitation of skin damage depth in burn area and determined a more superficial location of leukocytes barrier. Second, such influence of the light stream optimized acute inflammatory response, activated inflammation limitation mechanisms - forming dense and less wide leukocyte barrier (narrower for $45.8 \pm 2.4 \%(\mathrm{p}<0.01)$ in comparison with the placebo group. Diffuse infiltration by polymorphicnuclear leucocytes decreased, and weakened secondary alteration of skin tissues and underlying muscles. Third, it provided early stimulation of reparative processes in the deep layers of derma with participation of macrophages and lymphocytes, which determined fibroblasts activating in area of wound bottom and edges.

The PILER-light action caused stimulation of cicatrization mechanisms due to intensification of fibroblasts proliferation, both in area of wound bottom and edges. Morphologically it revealed in active granulations 


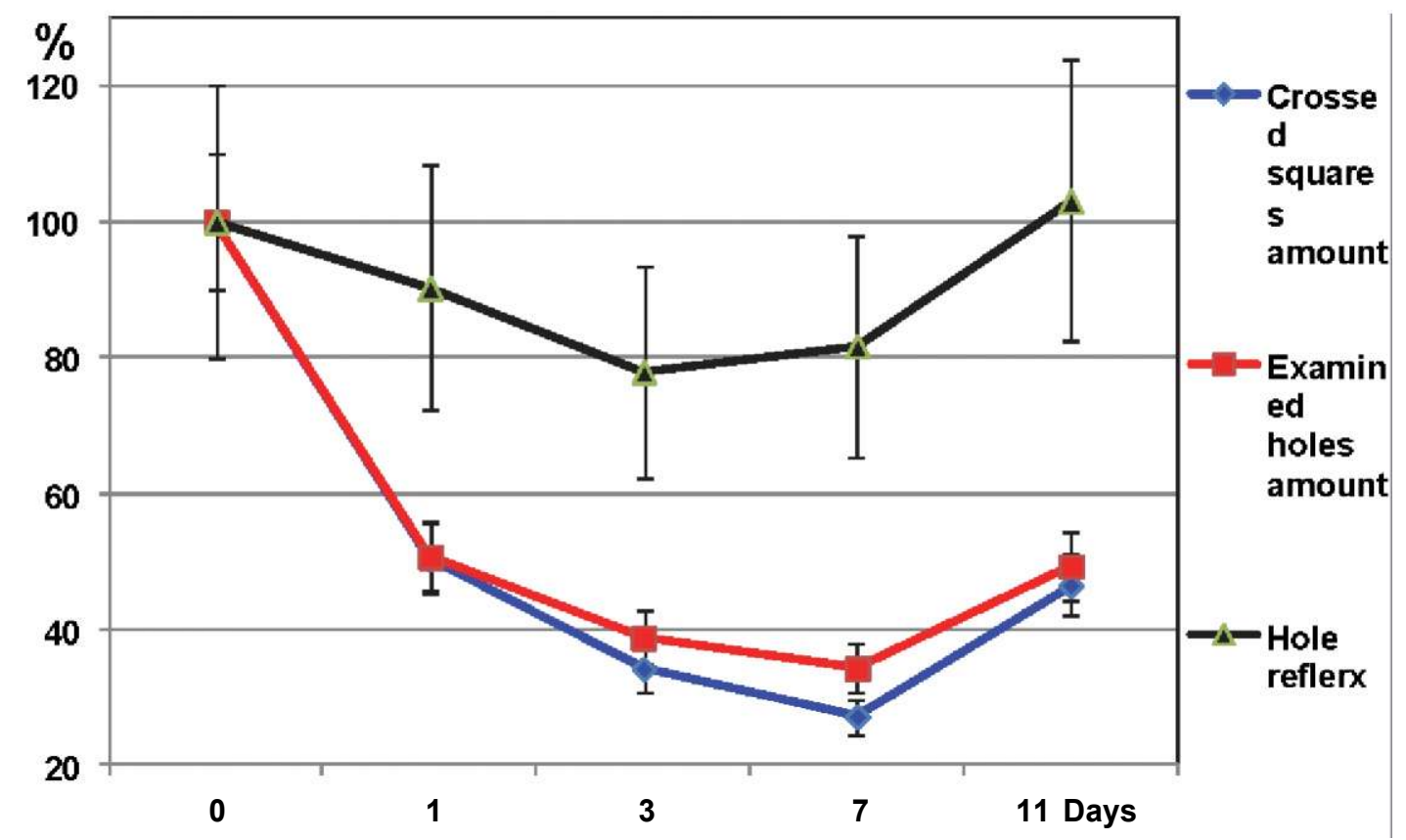

Fig. 2. Negatively influence of burn damage on the functional state of central nervous system

forming, stimulation of proliferation and migration of keratinocytes, that promoted epithelization of wound surface.

PILER-light stipulated early stimulation of reparative regeneration in the depth of derma - on the border with muscles. In the phase of granulation it intensified fibroblasts and endotheliocytes proliferation and stimulated wound surface epithelization. PILER-light, due to intensification of fibroblasts and endotheliocytes proliferation and stimulation of wound surface epithelization with the increase of epidermis thickness for $23.2 \pm 1.1 \%(\mathrm{p}<0.05)$ in relation to the group of comparison, accelerated cicatrization of the ambustial wound.

It is possible to explain these findings by presence of the electromagnetic field sensors in the human skin, to which belong activators of plasminogen and proteins of thermal shock. They support the epithelium homoeostasis and participate in skin regeneration [8]. Adenosine triphosphatase of membranes can «absorb» energy of electromagnetic waves and utilize it to fulfill chemical work. The enzymes of respiratory chain and Krebs cycle can absorb energy from infra-red range. Absorption of energy and electrons delocalization resulted in co-operation of proteins and DNA of cells. Thus, the energy of the polarized light influenced directly the cells of wounded surface and non-injured areas of skin, where it was absorbed.

Recovery of cells power balance promotes stimulation of keratinocytes, endotheliocytes and fibroblasts, ability to restore proliferation and activate the DNA reparative system in the damaged autologous cells rises. As a result of energy quants direct delivery to mitochondrium there occurs cytochrome oxidase activation, recovery of tissue respiration and ATP synthesis, which is important for ambustial wound healing processes.. Cellular NOS is an enzyme which takes in light and activates, stimulating the nitrogen oxide synthesis. It, as a powerful vasodilator, promotes dilation of small vessels and improvement of microcirculation in a burn wound [8]. There occurs a more physiological regeneration of many structures function, located in derma (nerve endings, sweat, greasy glands and hair follicles).

In our researches, the polarized light rendered adaptation-stimulant influence on general locomotor activity and motivational descriptions of animals. High ability to activate the antinociceptive systems of brain was supported, reliable increase of indexes testified to it, characterizing the state of CNS. The amount of crossed squares increased for $338 \%(p<0.001)$, and reached $438 \%$ and the number of examined holes for $204 \%(\mathrm{p}<0.001)$ and reached $304 \%$ mice displayed decline of anxiety, fear and uncertainty in comparison with the comparison group.

Fig. 2 shows the evolution of central nervous system disorders caused by the effects of burn injury. After multiple light applications, these variables achieved the norm (fig. 3).

PILER-light influenced positively on the sanogenetic mechanisms of CNS adjusting functional intercommu- 


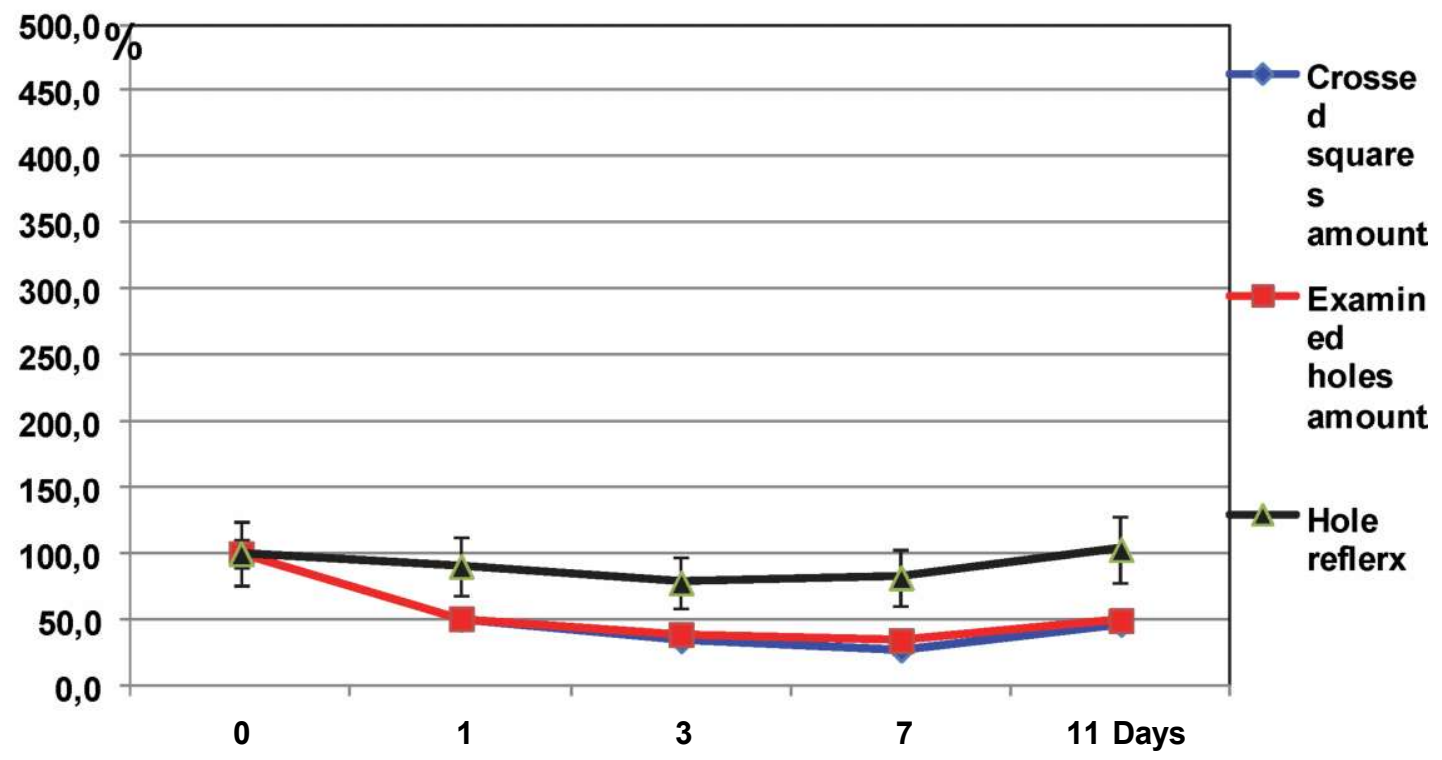

Fig. 3. Positively influence of PILER-light on the functional state of central nervous at the background of burn injury

nications, diminished pain and stress-reaction of organism and clinical displays of encephalopathy (fig. 4).

NOS - nitric oxide synthase; HPA (ACTH) - hypothalamus-pituitary-adrenalaxis (adrenocorticotropichormone, corticotropin); HPT (TSH) - hypothalamus-pituitary-thyroidaxis (thyroidstimu-latinghormone); RBC - red blood cell; WBC - white blood cell; ATP - adenosine triphosphate
Exactly in skin, which is rich in nervous fibers and completions, there begins transformation of the external electromagnetic fields of the polarized light in signals, which cause physiological answers. At moderate irritating influenced the peripheral secretion of hormones and hormone like peptides rendered the powerful stimulant influence on the whole organism. These hormones activated the receptors of skin cells

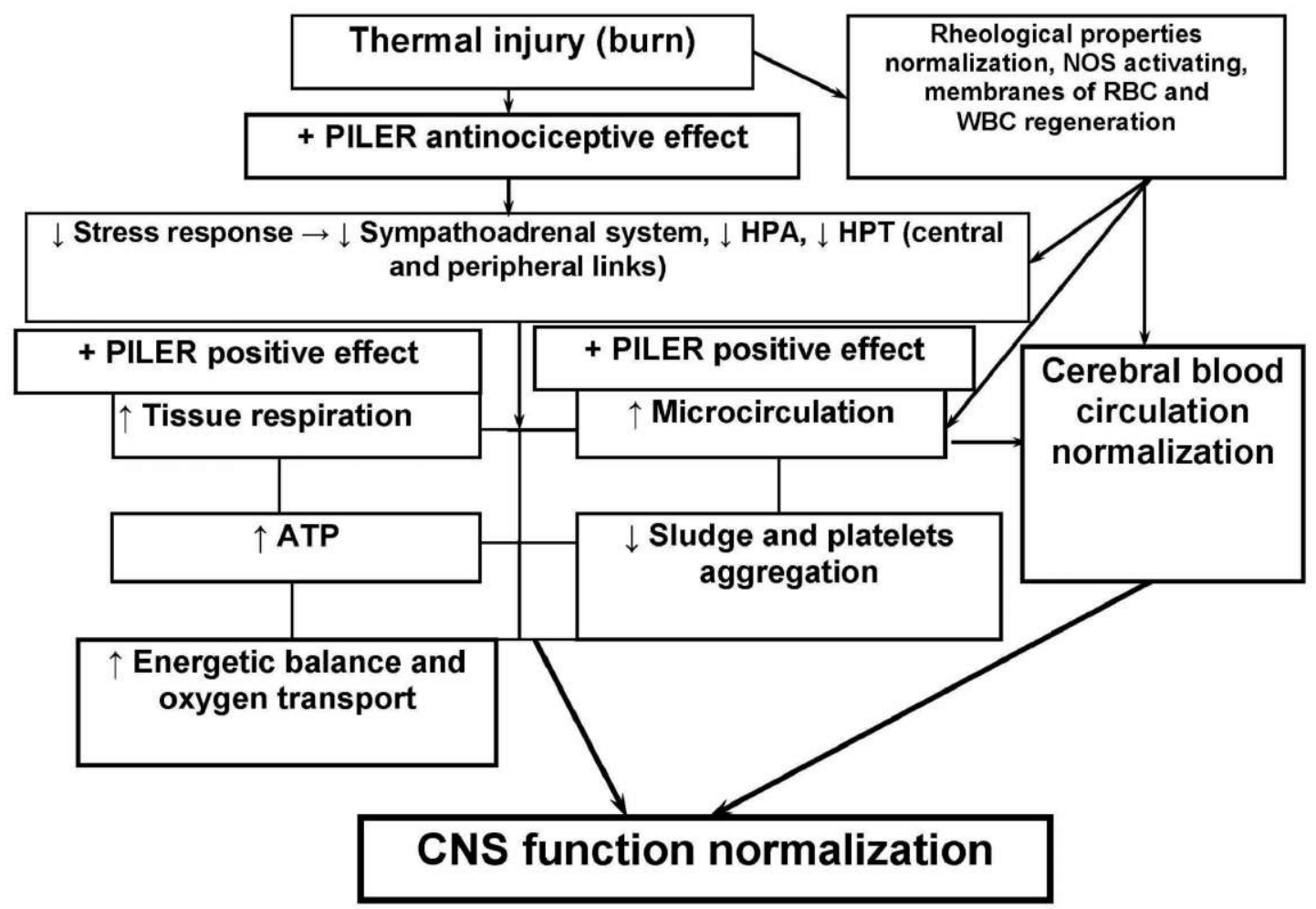

Fig. 4. PILER-light positively influence on the central nervous system 
membranes, and also fibers of somatic and vegetative nerves.

The results of the researches allow asserting that the certain areas of skin execute the functions of extraocular photoreceptors and are the part of the sensory ecoceptive system, which provides co-operation of organism with external electromagnetic waves [8].

At pain syndromes, it is possible to trace all the links of nascent reactions, including the receptors of electromagnetic waves of the polarized light on the nociceptive (opioid) structures of CNS.

Conclusions. It is possible to establish that the polychromatic polarized light application at the dosed burns by open flame positively influences on the morphogenesis of burn wound and CNS functional state.

The obtained data, on the one hand, discover the before unknown mechanisms of burns pathogenesis by open flame. On the other hand, they present base for correction by light and methodical recommendations of providing medical help for patients with burn trauma as monotherapy, in complex therapy, for the prophylaxis of complications and rehabilitation improvement.

It is experimentally well-proven that the polychromatic polarized light (PILER) can be used for treatment and decrease of incapacitating degree and lethality at injured with burns.

\section{References.}

1. Peck M. D. Epidemiology of burns throughout the world. Part I: Distribution and risk factors // Burns. 2011; 37(7):10871100 .

2. Shah A. Epidemiology and profile of pediatric burns in a large referral center/ Shah A., Suresh S., Thomas R. et al. // Clinic. Pediatr. (Phila), 2011; 50(5):391-5.

3. Yao Y. The epidemiology of civilian inpatients' burns in Chinese military hospitals, 2001-2007 / Yao Y., Liu Y., Zhou J. et al. // Burns, 2011; 37(6):1023-32.

4. Guillot M. Physiotherapy for the treatment of scarring due to serious burns // Proceedings of the 12th Congress of the European Burns Association: Abstracts. Budapest; 2007.

5. Oliveira P. C. Evaluation of the effects of polarized light (A 400-2000 nm) on the healing of third-degree burns in induced diabetic and nondiabetic rats / Oliveira P. C., Pinheiro A., de Castro I. C. / Photomed. Laser Surg, 2011; 29(9):619-625.

6. Monstrey S. A. conservative approach for deep dermal burn wounds using polarised-light therapy / Monstrey S., Hoeksema H., Saelens H. et al. // Br. J. Plast. Surg, 2002; 55:420-6.

7. Brusnitsyna M. V. BIOPTRON-2 application in complex intensive treatment of face and airways burns. Anthology of light therapy. Proceedings. Gulyar S. A., Editor-in-chief // Kyiv: Bogomoletz Institute of Physiology at the National Academy of Sciences of Ukraine and Shupyk National Medical Academy of Postgraduate Education at the Ministry of Health of Ukraine, 2009: 362-4. Russian.

8. Anthology of light therapy. Medical BIOPTRON technologies (theory, clinical application, prospects). Proceedings. Gulyar S. A., Editor-in-chief // Kyiv: Bogomoletz Institute of Physiology at the National Academy of Sciences of Ukraine and Shupyk National Medical Academy of Postgraduate Education at the Ministry of Health of Ukraine; 2009. Ukrainian, Russian.

9. BIOPTRONPILERlight application in medicine / Gulyar S. A., Kosakovsky A. L., editors. - Kyiv: Bogomoletz Institute of Physiology at the National Academy of Sciences of Ukraine and Shupyk National Medical Academy of Postgraduate Education at the Ministry of Health of Ukraine; 2006.Ukrainian; 2nd ed. 2011. Russian.

10. Gulyar S. A. Pain color therapy / Gulyar S. A., Limansky Yu. P., Tamarova Z. A. - Kyiv: Bogomoletz Institute of Physiology at the National Academy of Sciences of Ukraine; 2007. Russian.

11. Elskii V. M. Modeling method dosed thermal burn / Elskii V. M., Krivobok G. K., Kryuk Yu. Ya. et al. // Ukraine patent u 201001899. 2010 Aug (2552390 MPK G09B 23/28 (2006.01). Bul 16. Ukrainian. 